Katarina Eskola

\title{
Kulttuurinen muutos, elämäntapa ja vapaatavoitteinen sivistys
}

\begin{abstract}
"Pian päättyvän vuosituhannen viimeisinä vuosina Suomen kulttuurissa esiintyy kenties suurempaa eriaikaisuuden samanaikaisuutta kuin koskaan ennen. Yhtä aikaa ovat läsnä protestanttisen työetiikan läpitunkeman vanhemman polven yksisuuntaiset tulevaisuushorisontit ja joustavampien, tilannekohtaisesti vaihdettavien pilareiden varaan elämänsä ripustavien nuorten elämänodotukset."
\end{abstract}

\section{Eteenpäin menemisen eetos}

Tänään saatamme jotenkin melkeinpä hämmästellen tajuta, kuinka vahvasti tällä vuosisadalla ajateltuun ja tehtyyn on Suomessa liittynyt eteenpäin menemisen eetos. Sotien aikana tai Pian niiden jälkeen syntyneiden eli ns. Suuren murroksen sukupolven (vrt. Roos 1988) elämän koordinaatit olivat yksinkertaisia ja selviä. Elämänkulun ajateltiin etenevän lineaarisesti. Jos pääsi kouluun, opiskeli ja hankki ammatin, saattoi sen jälkeen mitä todennäköisimmin mennä töihin. Sen jälkeen voikin sitten perustaa perheen ja aloittaa työstä ja kodista ammentavan itsenäisen elämän. Siihen kuului pitkänä projektina omistusasunnon hankkiminen ja sen itselle säästäen lunastaminen. Elämällä oli järjestys ja päämäärä; se oli 'puissa'.

Tavoitteellisen elämänkulun suunnitteleminen ja usein myös toteuttaminenkin oli mahdollista aikana, jota leimasi optimistinen kehitys- ja edistysusko. Sotien jälkeisessä Suomessa uskottiin myös, että on tärkeätä panostaa koulutukseen ja kulttuuriin. Kun itse kävin 19504uvulla oppikoulua, käytin aikakauteni kieltä ja puhuin luontevasti henkisestä sivistyksestä. (Esitin tyttökoululuokassani myös vakavissani, että meidän pitää aikuisina perustaa henkisten naisten yhdistys!)

Tutkijat puhuivat innostuneesti nykyaikaisesta tieteestä. Odotettiin, että tieteen ja teknologian uudet innovaatiot helpottavat ratkaisevasti ihmisten arkielämää - ja niinhän ne tietysti tekivätkin! Moni muistaa tarkkaan, miltä tuntui pestä ensimmäisen kerran pyykkiä automaattipesukoneella.

$$
\text { Tieto, tasa-arvo ja hyvinvointivaltio }
$$

Suomen kaltaisissa vaurastuvissa länsimaissa 'paremman' elämän tavoitteiden toteutumista tuki laajeneva hyvinvointivaltio. Kehittyessään se turvasi asuinpaikasta sekä taloudellisesta ja sosiaalisesta asemasta riippumattomasti kaikille mahdollisuuden perustoimeentuloon ja terveyteen.

Hyvinvointivaltiota rakennettaessa vahvistettiin myös sivistyksen edellytyksiä. Keskeistä oli eräiden pysyvien kulttuurin perusinstituutioiden luominen ja muokkaaminen. Kaikkia väestöryhmiä koskevia uudistuksia oli yhtenäiskoulujärjestelmä, joka merkitsi peruskoulun vakiintumista Suomessa. Myös peruskoulua seuraavat jatkokoulutusmuodot korkeakouluista muihin aikuisoppilaitoksiin laajenivat. Yleisradio toteutti ohjelmapolitiikassaan kansansivistäviä tavoitteita. Yleisten kirjastojen ja opistojen verkko täydentyi. 
Moderni hyvinvointivaltio ei Suomessa kasvanut tyhjästä. Sen taustalla olivat muun muassa varhaisissa kansanliikkeissä vahvistuneet sosiaalisen oikeudenmukaisuuden ja tasa-arvon ideaalit. Kun käytettävissä oli 1960-luvulta lähtien enenevästi yhteiskuntatieteisiin perustuvaa rationaalista tietoa ihmisten yhteistoiminnan edellytyksistä, meillä toteutetusta pohjoismaisesta hyvinvointimallista tuli kansainvälisesti arvostettu kollektiivisen vastuun järjestelmä.

Modernin elämän suunta oli siten jatkuvasti nouseva, niin kuin sitä on joskus luonnehdittu. Moderniin edistysuskoon kuului ajatus, että tulevaisuus on pysyvästi eilistä parempi. Siihen kuului myös luottamus siihen, että tekemällä lujasti työtä pääsee eteenpäin. Omavaraisuuden ihanteen rinnalla eli vahvana ajatus kollektiivisesta vastuusta. Samalla kun uskottiin, että huominen on pysyvästi eilistä parempi, uskottiin myös, että se on kaikkia varten. Suomi rakensi hyvinvointivaltiota tasa-arvoisen osallistumisen ideaali sydämellään.

Koulutus- ja kulttuuripolitiikan suuria tulevaisuuden kysymyksiä on, kuinka Suomessa jatkossakin taataan tasa-arvoisuus sivistyksellisen pääoman hankkimisessa ja käyttämisessä tästä eteenpäin. Tuoreet mielipidemittaukset osoittavat, että kansalaiset tukevat hyvinvointivaltioksi kutsuttua järjestelmää, jonka piiriin kuuluu myös sivistyksen julkinen tuki. Elinkeinoelämän valtuuskunnan kesäkuussa 1995 päivätty raportti hyvinvoinnista ja julkisesta taloudesta kertoo selvin sanoin, että "yksityisen toimeliaisuuden lisäämisen kannatus on heikentynyt ja kahden viime vuoden aikana mielipideilmastossa on palattu takaisin julkisen sektorin puolustamiseen päin". EVA:n uusimmat hyvinvointipalveluja koskevat asennemittaukset oli tehty vuonna 1992 ja 1994. (Ks. Uudistuva ... 1995)

\section{Uusi aika ja sukupolvierot}

Suuri osa nykysuomalaisista on kasvanut tai elänyt varhaislapsuutensa edellä luonnostellussa modernin kulttuurissa. Tavalla tai toisella monet ovat olleet sitä myös luomassa. Tänään, 1980-luvun talouden hulppeiden vuosien jälkeisellä 1990-luvulla, selkeiden tulevaisuushorisonttien aika on ohitse. Epävarmuuden aika osuu yksiin suurtyöttömyyden kanssa.

Yhteiskunnan ja kulttuurin uuteen tilaan liittyy uudentyyppisiä jännitteitä vanhemman ja keski-ikäisten polven ja nuorten välille. Nyt, pian päättyvän vuosituhannen viimeisinä vuosina, Suomen kulttuurissa esiintyy kenties suurempaa eriaikaisuuden samanaikaisuutta kuin koskaan ennen. Yhtä aikaa ovat läsnä protestanttisen työetiikan läpitunkeman vanhemman polven yksisuuntaiset tulevaisuushorisontit ja joustavampien, tilannekohtaisesti vaihdettavien pilareiden varaan elämänsä ripustavien nuorten elämänodotukset.

Vanhemman sukupolven on vaikea suunnistautua tilanteessa, jossa suhde työhön on ulkoisista syistä käynyt epävarmaksi. Pulan ja murroksen polven ei liioin ole helppoa omaksua markkinatalouden puhe- ja toimintatapoja.

Esitelmöidessään suomalaisuuden logiikoista Helsingin yliopistossa toukokuussa 1995 järjestetyssä Suomalainen mentaliteetti -symposiumissa professori Antti Eskola kertoi, kuinka pankinjohtajat 1980-luvulla houkuttelivat ihmisiä ottamaan lainaa ja sijoittamaan. Tekojen seurauksena piti oleman rikastuminen. Vaikka Eskola uskoi tällaiseen 'lakiin', hän ei ottanut lainaa. Kielteisen päätöksen takaa löytyi kulttuurinen malli. Pikkutilalla 1930- ja 1940-luvulla kasvaneena Eskola tukeutui sen aikaisiin kaavoihin; niitä leimasi pyrkimys omavaraisuuteen. Eskolan mukaan hänessä vaikuttaa edelleen pienviljelijämäiseksi omavaraisuudeksi kutsuttavissa oleva kulttuurinen ydinlogiikka.

Nuoremmat sukupolvet ovat kohdanneet uuden ajan haasteet siinä elämänkaarensa vaiheessa, jolloin he ovat muovailtavimmillaan. Nykynuorilla ei alun alkaenkaan ole ollut samanlaisia yksimuottisia 
elämänsuunnitelmia kuin vanhemmilla polvilla. Nuoret ovat kasvaneet sukkuloimaan tilanteesta toiseen, niin kuin nuorten elämänsisältöjen muutoksia väitöskirjassaan tutkinut Lasse Siurala (1994) toteaa.

Vaikka nuoret saattavatkin pitää työtä tärkeänä, ensisijaisena elämänsisällön antajana se mainitaan 1990-luvulla selvästi harvemmin kuin 1970- ja 1980-luvulla. Myös kodin merkitys on eri vuosikymmenillä tehtyjen kyselytutkimusten tulosten mukaan vähentynyt. Merkitystään onkin kasvattanut lähinnä vapaa-aika, jonka piiristä yhä useampi 1990-luvun nuori sanoi saavansa tärkeimmän elämänsisältönsä. (Mts. 227-228.)

\section{Kulttuuriharrastusten luvattu maa}

Sekä peruskoulun että muiden nuorten koulutusteiden opetussuunnitelmille nuorten elämän uudet ulottuvuudet samoin kuin yleisemmin modernin elämäntavan eheyden mureneminen asettavat haasteita. Lasse Siuralan tavoin on kysyttävissä, kuinka nuorten elämänsfäärejä voidaan nykyistä paremmin sovittaa yhteen myös niissä instituutioissa, jotka vastaavat koulutuksesta.

Kulttuurisen muutoksen esiinnostamat koulutukselliset ja sivistykselliset haasteet eivät koske pelkästään nuoria. Yksisuuntaisen etenemisen eetoksen mureneminen asettaa kaikelle koulutukselle ja vapaatavoitteiselle sivistystyölle uusia odotuksia ja myös huomattavia mahdollisuuksia.

Tänään puhutaankin enenevästi elinikäisestä koulutuksesta. Uusi kulttuurinen tila edellyttää jatkuvaa oppimista ja tiedon eri alojen rajojen ylityksiä. Tulevaisuuden sivistyspolitiikassa joudutaan tätä sarkaa kyntämään uusin näkemyksin.

Suomen ja sen kulttuurin suuria etuja ja tunnusmerkkejä on laajalle ulottuva koulutuksellinen perussivistys. Myös vapaatavoitteiseen sivistystoimintaan osallistutaan runsaasti. Taiteen ja kulttuurin harrastus on Suomessa kansainvälisesti arvioiden huomattavan yleistä, niin kuin maan kulttuuripolitiikan tuoreet kansalliset ja kansainväliset selvitykset ja arviot osoittavat (vrt. Cultural policy... 1994; National cultural policy... 1995).

Kulttuuritoimintaan osallistuminen jakaa kuitenkin väestöä sukupuolen mukaan. Naiset harrastavat perinteellisiä taidemuotoja miehiä yleisemmin, ja naiset osallistuvat myös muuhun ruohonjuuritason kulttuuritoimintaan miehiä ahkerammin. He osallistuvat innokkaammin vapaa-aikana tapahtuvaan aikuisopetukseen, tapahtuipa se opistoissa tai täydentävää koulutusta antavissa muissa laitoksissa. (Eskola 1985; Liikkanen 1994)

\section{Kolmannen alueen mahdollisuudet}

Naiset ovat siten huomanneet työn ja perheen rinnalla olevan kolmannen alueen ja oppineet käyttämään sen suomia toimintamahdollisuuksia laajasti omaksi ja yhteisönsä hyväksi. Sosiaalipolitiikan professori Antti Karisto on viime aikoina eri yhteyksissä korostanut, kuinka tärkeää olisi yhdistää kulttuurin alan työtä ja toimintaa sosiaalipolitiikkaan. Hänen mielestään meidän protestanttisen työetiikan "raskauttamassa" kulttuurissamme kolmannella alueella ei ole ollut samanlaista yhteisöllisesti tunnustettua arvoa kuin työllä ja perhe-elämällä.

Kolmannella alueella Karisto tarkoittaa yhteisöllisen elämän, itsensä toteuttamisen ja vapaa-ajan vieton kenttää sekä modernien palvelujen aluetta: "Kolmas alue tarjoaa harrastusmahdollisuuksia ja elämänsisältöjä, mahdollisuuksia erimuotoiseen osallistumiseen ja yhteisöllisyyteen. Se tarjoaa erilaisia työn ja perheen vaatimuksia yhteensovittavia, arkielämää helpottavia palveluja, esimerkiksi toimivaa joukkoliikennettä osallistumisen tueksi. Se tarjoaa paikallista kiinnittymistä ja yhteisöllisiä ylpeydenaiheita. Kulttuuria ja urheilua, kahviloita ja kirpputoreja, kaupunginosatapahtumia ja katusoittoa, aikuisopiskelua ja onnenpelejä." (Karisto 1994, 28) 
Monet merkit viittaavat jo tänään siihen, että työn ja perheen rinnalle on noussut ja nousemassa elämänlaatua kohentava vapaa-aika moninaisine tekemisiin ja uuden oppimisen mahdollisuuksineen. Kolmannella alueella tapahtuu enemmän kuin ennen.

Sen piiriin kuuluvat myös vapaatavoitteisen sivistyksen tarjoaminen ja omaksuminen. Aktiivinen itsensä toteuttaminen vapaa-ajan toiminnoissa ei ole jotakin ylimääräistä vaan osa kokonaista elämää. Harrastuksista on lupa puhua ääneen.

\section{Esteettinen, ekologinen ja eettinen}

Saattaa olla, että kolmannella alueella ja kansalaisyhteiskunnassa kirkastuvat myös monet Suomen kulttuuria koskevat yleiset kysymykset. Isojen linjausten merkitys konkreettistuu helpommin lähiyhteisössä. Voikin vain jäädä toiveikkaana odottamaan, että suomalainen sivistys syvenee ja laajenee tätä kautta ympäristöä, luontoa ja kulttuurimaisemaa arvostavaan suuntaan.

Viime kädessä sivistyksessä on kysymys siitä, miten ihmiset ratkaisevat yhteiskunnan ja luonnon välisen suhteen. Tarvitaan jatkuvia rajanylityksiä ja uusia, yhdistäviä tarkastelukulmia. Suomalaisessa sivistyksessä on tällä kohdin puutteita. Kuitenkin on jo alkanut tulla tietoa siitä, että ihmisten esteettisissä elämyksissä korostuvat nykyään myös ekologiset puolet.

Ehkä tulevaisuuden vapaatavoitteisen sivistystyön piirissä järjestetään kolmen e:n kursseja eli puhutaan yhtä aikaa esteettisestä, ekologisesta ja eettisestä tietämyksestä.

\section{LÄHTEET}

Cultural policy in Finland. National report 1994. European programme of national culturalpolicy reviews. Helsinki: Finnish Ministry of Education.

Eskola, Antti 1995. Suomalaisuuden logiikoista. Esitelmä Suomalainen mentaliteettisymposiumissa Helsingin yliopistossa 18.5.1995.

Eskola, Katarina 1985. Naiset kokonaisen elämän etujoukkona. Teoksessa Noidannuolia. Tutkijanaisten aikakirja. Toim. Auli Hakulinen ym. Helsinki: Gaudeamus, 187-200.

Karisto, Antti 1994. Potkua paikallisyhteisöihin. Näkökulma ehkäisevään sosiaalipolitiikkaan. Sosiaaliturva 1994:9, 26-31.

Liikkanen, Mirja 1994. Yleisö - taidemaailman äänetön osapuoli. Hyvinvointikatsaus 1994:2, 10-14.

National cultural policy in Finland. Interim report of a European group of experts by Jacques Renard 1995. Council for Cultural Co.operation.

Roos, J.P. 1988. Elämäntavasta elämäkertaan. Helsinki: Tutkijaliitto.

Siurala, Lasse 1994. Nuoriso-ongelmat modernisaatioperspektiivissä. Helsingin kaupungin tietokeskuksen tutkimuksia 1994:3.

Uudistua vai kuihtua. Raportti hyvinvoinnista ja julkisesta taloudesta 1995. Helsinki: Elinkeinoelämän valtuuskunta (EVA). 